\title{
Effect of Poverty and Economic Growth on Indonesia Human Development Index
}

\author{
Heppi Syofya ${ }^{1}$ \\ STIE Sakti Alam Kerinci ${ }^{1}$ \\ email : hsyofya@gmail.com
}

\begin{abstract}
Human development is defined as a process for enlarging people's choices, the Human Development Index is a benchmark of human development achievement based on a number of basic components of the quality of life of IPM is built through a basic three-dimensional approach that is 1). Dimensions of longevity and healthy life (a long and healthy life), 2). Knowledge and 3). Decent standard living, through the improvement of these three indicators is expected to increase the quality of human life due to individual heterogeneity, geographical disparity and societal conditions vary so that the level of income is no longer the main benchmark in calculating the success rate of development and success, poverty is a condition that is below the minimum standard of needs, both for food and non-food items called the poverty line or poverty threshold, the poverty rate and economic growth have a significant effect on the Index Human Development in Indonesia and economic growth have an influence on the Human Development Index in Indonesia
\end{abstract}

Keywords : IPM, growth economic

\section{PRELIMINARY}

Man is the real wealth of the nation, human development puts man as the ultimate goal of development, not the tools of development. The ultimate goal of development is to create an environment that enables people to enjoy long, healthy, and productive life (United Nations Development Program UNDP). It seems simple, but it is often overlooked by shortterm work to collect wealth and money. Human development is defined as a process of multiplying human choices (a process of enlarging people's choices). Among the many options, the most important choice is to live long and healthy, to have knowledgeable knowledge, and to have access to the resources needed to live properly (BPS, 2017). To see how far the success of human development United Nations Development Program (UNDP) has issued an indicator that is Human Development Index or Human Development Index (HDI). According to UNDP (in BPS, 2017), the Human Development Index is a benchmark of human development achievement based on a number of basic components of quality of life, as a measure of quality of life, IPM is built through a basic three-dimensional approach: 1). Dimensions of longevity and healthy life (a long and healthy life), 2). Knowledge (knowledge), and 3). Decent standard of living. The current development paradigm is economic growth measured by human development that is viewed with the level of quality of human life in each country, one of the benchmarks used in looking at the quality of human life is the Human Development Index (HDI) as measured by quality level of education, health and economy (purchasing power). Through the improvement of these three indicators, it is expected that there will be an increase in the quality of human life due to individual heterogeneity, geographical disparity and societal conditions vary so that the income level is no longer the main benchmark in calculating the success rate of development and the success of human development cannot be separated from government performance which plays a role in creating regulation for the achievement of social order. Human development in Indonesia is synonymous with poverty reduction, 
investment in education and health care will be more meaningful to the poor than non-poor, because the main assets of the poor are their abuses. The availability of cheap educational and health facilities will greatly help to increase productivity, and in turn increase income thus it can be said that human development has not been optimally done because it only focuses on poverty reduction. By the end of 2016 the number of poor people in Indonesia has a relatively high poverty rate of 28.6 million people with a percentage of $10.9 \%$ with Gross Regional Domestic Product (GRDP) of 12.406 trillion and higher than in the previous year (BPS, 2017). Government policy through regional autonomy effective from 1 January 2001 which is marked by the birth of Law no. 23 of 2014 on local government and Law no. 9 Year 2015 on the financial balance between the central and regional levels provides an opportunity for local governments at both the provincial and district and city levels to develop their own potential areas. Regional autonomy provides the flexibility for each region to manage its budgets including in capital expenditures and the allocation of development programs. The objective of the development program is to increase regional economic growth and reduce the number of poverty. The purpose of this study was to determine the effect of poverty rate and population growth on the human development index and to know the magnitude of the effect of poverty rate and population growth on human development index.

\section{LITERATURE REVIEW}

In human development there are important things that need to be the main concern (UNDP, 2004: 128), namely: 1). Development should prioritize the population as the center of attention, 2). Development is intended to enlarge choices for the population, not only to increase their income; therefore, the concept of human development must be centered on the population as a whole, and not just on the economic aspects alone, 3). Human development is concerned not only in efforts to improve human capabilities (capabilities) but also on efforts to utilize human capabilities optimally, 4). Human development is supported by four main pillars, namely: productivity, equity, sustainability, and empowerment, and 5). Human development is the basis for determining development objectives and in analyzing the options for achieving them. Based on the above explanation, it is necessary to note further the four main pillars that support human development, further described UNDP (2004), the four main pillars that support human development are: 1). Productivity, communities must be able to increase their productivity and participate fully in the process of earning and wage employment. Therefore, economic growth is one part of the kind of human development, 2). Equity, communities must have access to equitable opportunities. All obstacles to economic and political opportunities should be removed so that people can participate in and benefit from these opportunities, 3). Sustainability, access to opportunity must be ensured not only for present generation but also future generations. All forms of physical capital, human, living environment, must be completed, 4). Empowerment, development must be done by the community and not just for them. Communities must participate fully in making decisions and processes that affect their lives.

Human development is essentially to expand the choice for the society with the ultimate goal of achieving the welfare of each member of society so that human development in this case also includes various other aspects, besides economic aspects there are also social, political, cultural and other aspects to make people more productive in activity. Thus the paradigm of human development includes two sides, namely the form of human capabilities such as improving health, 
education and skills. The other side is the utilization of their capabilities for productive, cultural, social and political activities. This aspect of human development can be seen from the Human Development Index (HDI). This Human Development Index is an alternative measurement of development in addition to using Gross Domestic Gross. The value of a country or territory's IPM indicates how far the country or region has achieved the prescribed goals of life expectancy, basic education for all levels of society (without exception), and the level of expenditure and consumption that has reached an adequate standard of living. The level of education and individual health of the population is a dominant factor that needs to be given top priority in improving the quality of human resources. With high levels of education and health of the population determine the ability to absorb and manage the sources of economic growth both in relation to technology to the important institutions in an effort to improve the welfare of the population itself which all lead to advanced economic activity. One indicator in analyzing economic development is economic growth. Economic growth shows how far economic activity will produce. Given economic growth, it is expected that the income of the community as the owner of the factors of production will also increase, to measure Economic Growth is the growth rate of Gross Domestic Product (GDP) reflecting the amount of added value generated by all production activities in the economy.

According to Sukirno (2005: 78) defines economic growth as a long-term increase in the ability of a country to provide more types of economic goods to its inhabitants. This capability grows according to technological progress, and the institutional and ideological adjustments it needs. This definition has 3 (three) components: first, the economic growth of a nation is seen from the continuous increase of inventory; advanced technology is a factor in economic growth that determines the degree of capability growth in the provision of various goods to the population; thirdly, the widespread and efficient use of technology requires adjustment in the institutional and ideological fields so that innovations produced by human science can be exploited appropriately, in an open economy means in the economy there are households, the corporate sector, the government sector and the foreign sector, to determine the magnitude of national income in this open economy as well as to calculate the national income of the economy discussed earlier by summing the expenditures of the economic sectors. Economic growth is the development of activities in the economy that cause goods and services produced to increase and prosperity increases. High and sustainable economic growth is a prerequisite for economic development. The continuing poverty in many African countries is one of the consequences of the absence of economic growth in these countries. Therefore, the problem of economic growth has received much attention from economists, both in developing countries and industrialized countries.

According to Todaro (2006: 79), globalization is a process that the world economy increasingly united, boosting the global economy and increasingly globalize economic policy making. Globalization means an increase of a country's economic openness to international trade, international flow of funds, and foreign direct investment, the economy indicating the extent to which economic activity will generate additional income for a given period of time. The indicator used to measure Economic Growth is the growth rate of Gross Domestic Product (GDP) reflecting the amount of added value generated by all production activities in the economy. According to Kuznets in Todaro (2006: 112), economic growth is a longterm capacity increase of the country concerned to provide various economic 
goods to its population. The increase of capacity itself is determined or made possible by technological, institutional (institutional) and ideological changes or adjustments to various demands. Kuznets also points out that there are at least six characteristics or characteristics of the economic growth process found in almost all countries that now have developed countries or developed regions when speaking in the context of regional economies. Six characteristics of the process of economic growth according to Kuznets are:

1. High growth rate of output per capita and population growth,

2. High factor productivity increase rate,

3. High level of structural economic transformation,

4. High level of social transformation and ideology,

5. The tendency of countries that start or have advanced their economy to try to increase the share - the rest of the world as a new marketing and feedstock area, and

6. The limited spread of economic growth reaches only about one-third of the population.

According to Sukirno (2005: 147) explains that in macroeconomic analysis, economic growth has two different aspects of understanding. On the one hand, economic growth is used to describe an economy that has undergone economic development and reach a higher level of prosperity. On the other hand, economic growth aims to illustrate the economic problems faced by a country or region in the long term. The problem of economic growth itself is divided into three aspects, namely: 1). Aspects derived from the difference between the potential growth rate that can be achieved with the actual rate of economic growth achieved. Current investments can increase the stock of capital goods in the future so that the potential of a country or region to produce goods and services will increase as well. Technological advances, population growth and productivity growth can also increase the production of goods and services. Furthermore, the increase of these factors does not necessarily increase economic growth to its potential level. On the contrary, what is happening is slow economic growth, greater unemployment, and problems beyond the economic (social, pilitik, defense and security) issues that are increasingly complex, 2). The next aspect is to increase the growth potential itself. When a country or region needs economic growth by looking at a certain number of GDP to reduce unemployment problems, but in reality GDP growth is not in accordance with the planned and will result in the occurrence of unemployment problems cannot be resolved, so the country or region needs to think of ways to accelerate the pace of economic growth and 3). The last aspect is about the persistence of economic growth that prevails from one year to another. The movement of economic growth faced by a country or region is always volatile. There is a sense of rapid growth, and sometimes run slow even lower than the previous year.

Economic Growth in general, economic growth is defined as an increase in the ability of an economy to produce goods and services. Economic growth is one of the most important indicators in analyzing the economic development that occurs in a country. Economic growth as reflected in the GRDP or GDP of a region can indicate the extent to which the economic activities will result in additional income for a given period of time. Because basically economic activity is a process of using production factors to produce output, then this process will in turn produce a flow of remuneration to the factor of production owned by society. With the economic growth it is expected that the income of the community as the owner of factors of production will also increase. In other words, economic growth refers to quantitative change and is usually measured using Gross Domestic Product 
(GDP) data or the total market value of final goods and services final goods and services) generated from an economy over a period of time (usually one year).

Menurut Todaro (2006: 128) menyatakan bahwa IPM Indek romantis adalah pengembangan manusia yang didasarkan pada aspek kesehatan, pendidikan, dan kesejahteraan masyarakat. Rendahnya IPM akan memungkinkan pada rendahnya produktivitas kerja dari penduduk. Produktivitas yang rendah memungkinkan rendahnya pendapatan, Provinsi menghitung jumlah penduduk miskin. Dalam hal ini, Indeks Pembangunan Manusia (IPM) atau Indeks Pembangunan Manusia (IPM) yang merupakan hasil indentitas untuk mengukur pencapaian kualitas pembangunan manusia. Kemiskinan dapat membuat perubahan yang cukup penting bagi orang-orang yang memiliki masalah yang kompleks yang dapat digunakan untuk mencukupi kebutuhan dasar yang diperlukan untuk kesehatan dan kesehatan (Mirza, 2012).

According to Subandi (2012: 156) states one of the strategies / efforts to alleviate poverty is to build human resources (HR). Development of human resources can be done by improving access to the consumption of social services (education, health, and nutrition) is a government strategy to reduce poverty and improve welfare. Human development can be measured by the Human Development Index (HDI) or Human Development Index (HDI), which is a composite index to measure the achievement of the quality of human development. According to Ginting (2008: 124) states human development in Indonesia is synonymous with poverty reduction. Investments in education and health care will be more meaningful to the poor than non-poor, since the main assets of the poor are their abuses. The availability of cheap educational and health facilities will greatly help to increase productivity, and in turn increase revenue. Thus it can be said that human development has not been optimally done because it only focuses on reducing poverty.

According to Subandi (2012: 145) In this case explains that social development is a development approach explicitly trying to integrate the process of economic and social development. Social development cannot work well without economic development, while economic development is meaningless unless followed by increasing social welfare of the population as a whole. Economic development or more precisely economic growth is a prerequisite for the achievement of human development because with the assured economic development increased productivity and increased income through job creation. The relatively high level of human development will affect the performance of economic growth through population capability and the consequence is the increase of people's productivity and creativity. With the increased productivity and creativity, the population can absorb and manage the resources that are essential for economic growth.

\section{RESEARCH METHODS}

The type of data used in this study is secondary data obtained from Badan Pusat Statistik (BPS) Indonesia Year 2017 and other supporting reports and references. To see the effect of Poverty Rate $\left(\mathrm{X}_{1}\right)$ and Economic Growth $\left(\mathrm{X}_{2}\right)$ on Human Development Index (Y) in Indonesia, the calculation formulas

$$
\mathrm{Y}=\mathrm{a}+\mathrm{b}_{1} \mathrm{X}_{1}+\mathrm{b}_{2} \mathrm{X}_{2}+\mathrm{e}
$$

Where:

Y : Human Development Index (HDI)

A : Constant value

b1, b2 : Regression Coefficients

$\mathrm{X}_{1}$ : Poverty Rate

$\mathrm{X}_{2}$ : Economic Growth (GDP)

e : error/interrupt factor

$\log \mathrm{Y}=\log \mathrm{a}+\log \mathrm{b} 1 \mathrm{X} 1+\log \mathrm{b} 2 \mathrm{X} 2$ $+\mathrm{e}$

Coefficient Determination is an analysis used to determine the effect of a 
research variable, in this research is the influence of Poverty Rate $\left(\mathrm{X}_{1}\right)$ and Population Growth $\left(\mathrm{X}_{2}\right)$ on Human Development Index in Indonesia, with the equation:

$\mathrm{KD}=\mathrm{r} 2 \times 100 \%$

Where :

KD : Coefficient of determination

$\mathrm{r}$ : Correlation Coefficient

\section{RESEARCH RESULT AND DISCUSSION}

The table below shows that the number of poverty level in Indonesia for 10 years is $112.07 \%$ with an average poverty rate of $12.45 \%$ per year and the value of Indonesian human development index of $620.3 \%$ with the average value of HDI per year is $68.92 \%$.

Table 1

Level of Poverty, GDP and Human Development Index in Indonesia Year 2006-2016

\begin{tabular}{cccc}
\hline Year & $\begin{array}{c}\text { Poverty level } \\
(\boldsymbol{\%})\end{array}$ & $\begin{array}{c}\text { GDP } \\
\text { (Billion Rupiah) }\end{array}$ & $\begin{array}{c}\text { Human Development } \\
\text { Index }(\boldsymbol{\%})\end{array}$ \\
\hline 2006 & 17.75 & $3,339.20$ & 70.1 \\
2007 & 16.58 & $3,950.90$ & 70.6 \\
2008 & 15.42 & $4,948.70$ & 71.2 \\
2009 & 14.15 & $5,606.20$ & 71.8 \\
2010 & 13.30 & $6,864.40$ & 66.5 \\
2011 & 12.50 & $7,831.70$ & 67.1 \\
2012 & 12.00 & $8,615.70$ & 67.7 \\
2013 & 11.40 & $9,546.10$ & 68.3 \\
2014 & 11.20 & $10,565.80$ & 68.9 \\
2015 & 11.20 & $11,540.80$ & 69.6 \\
2016 & 10.90 & $12,406.80$ & 69.2 \\
Sum & $\mathbf{1 1 2 . 0 7}$ & $\mathbf{7 7 9 2 6 . 2}$ & $\mathbf{6 2 0 . 3}$ \\
Average & $\mathbf{1 2 . 4 5}$ & $\mathbf{8 6 5 8 . 4 7}$ & $\mathbf{6 8 . 9 2}$ \\
\hline
\end{tabular}

Source : BPS, 2017.

Table 2

Log Data Result of Poverty Level, GDP and HDI In Indonesia in 2006-2016

\begin{tabular}{cccc}
\hline Year & Log X1 & Log X2 & Log Y \\
\hline 2006 & 1.25 & 3.52 & 1.85 \\
2007 & 1.22 & 3.60 & 1.85 \\
2008 & 1.19 & 3.69 & 1.85 \\
2009 & 1.15 & 3.75 & 1.86 \\
2010 & 1.12 & 3.84 & 1.82 \\
2011 & 1.10 & 3.89 & 1.83 \\
2012 & 1.08 & 3.94 & 1.83 \\
2013 & 1.06 & 3.98 & 1.83 \\
2014 & 1.05 & 4.02 & 1.84 \\
2015 & 1.05 & 4.06 & 1.84 \\
2016 & 1.04 & 4.09 & 1.84 \\
Sum & $\mathbf{1 2 . 3 0}$ & $\mathbf{4 2 . 3 9}$ & $\mathbf{2 0 . 2 4}$ \\
Average & $\mathbf{1 . 1 2}$ & $\mathbf{3 . 8 5}$ & $\mathbf{1 . 8 4}$ \\
\hline
\end{tabular}

Source : processed date 
Table 3

Coefficients $^{\mathrm{a}}$

\begin{tabular}{|ll|r|r|r|r|r|}
\hline \multirow{2}{*}{ Model } & \multicolumn{2}{|c|}{$\begin{array}{c}\text { Unstandardized } \\
\text { Coefficients }\end{array}$} & \multicolumn{2}{c|}{$\begin{array}{c}\text { Standardized } \\
\text { Coefficients }\end{array}$} & \multicolumn{2}{|c|}{} \\
\cline { 2 - 7 } 1 & \multicolumn{1}{|c|}{ B } & Std. Error & \multicolumn{1}{c|}{ Beta } & \multicolumn{1}{c|}{ T } & \multicolumn{1}{c|}{ Sig. } \\
\hline & (Constant) & 12.503 & 7.048 & & 1.774 & .000 \\
& Poverty level & 2.007 & .940 & .002 & 4.008 & .002 \\
& GDP & 2.313 & 1.877 & 1.027 & 3.363 & .000 \\
\hline
\end{tabular}

$\mathrm{Y}=12,503+2,007 \mathrm{X}_{1}+2,313 \mathrm{X}_{2}$

If the level of poverty and GDP is considered zero then the Human Development Index (HDI) will increase by 12,503 units, the magnitude of the effect of the poverty level on the Human Development Index in Indonesia is $2.007 \%$, meaning that every $1 \%$ increase in poverty level, the Human Development Index in Indonesia will decrease by $2.007 \%$. From the results of the analysis, more appropriate government policies are needed in the program to increase the Human Development Index (HDI) and reduce poverty levels in the hope that development can be successful and targeted, and the magnitude of the effect of Economic Growth on Human Development Index in Indonesia is 2,313\% meaning that every $1 \%$ increase in Economic Growth, the Human Development Index in Indonesia will increase by $2,313 \%$.

Table 4.

Model Summary

\begin{tabular}{|l|r|r|r|r|}
\hline Model & \multicolumn{1}{|c|}{ R } & R Square & Adjusted R Square & \multicolumn{1}{c|}{ Std. Error of the Estimate } \\
\hline 1 & $.928^{\mathrm{a}}$ & .861 & .758 & .15767 \\
\hline
\end{tabular}

Based on the results of calculations through multiple linear correlation on the influence of the rate of poverty and economic growth on the Human Development Index in Indonesia with the test of all variables simultaneously, the resulting correlation $\mathrm{r}$ is equal to 0.928 , with R-Square is the percentage contribution variable Poverty and Economic Growth Human Development Index with the number 0.861 which is the quadruple of the correlation coefficient (0.928). This means that the contribution of variable poverty rate and economic growth on Human Development Index in Indonesia is $86.1 \%$ while the rest of $13.9 \%$ is influenced by other factors. To know the f-test Effect of Poverty Level and Economic Growth on Human Development Index simultaneously, it can be explained in the following table:

Table 5.

ANOVA $^{\text {b }}$

\begin{tabular}{|l|r|r|r|r|r|}
\hline Model & Sum of Squares & Df & Mean Square & F & Sig. \\
\hline 1 Regression & .618 & 2 & .206 & 8.292 & $.001^{\mathrm{a}}$ \\
Residual & .099 & 3 & .025 & & \\
Total & .718 & 10 & & & \\
\hline
\end{tabular}

a. Predictors: (Constant), poverty, GDP 
Table 5.

ANOVA $^{b}$

\begin{tabular}{|c|c|c|c|c|c|}
\hline Model & Sum of Squares & Df & Mean Square & $\mathbf{F}$ & Sig. \\
\hline 1 Regression & .618 & 2 & .206 & 8.292 & $.001^{\mathrm{a}}$ \\
\hline Residual & .099 & 3 & .025 & & \\
\hline Total & .718 & 10 & & & \\
\hline
\end{tabular}

a. Predictors: (Constant), poverty, GDP

b. Dependent Variable: IPM

F-arithmetic > F-table or 8,292> 5.41 or can be seen from the significance test that is $0.001<0.05$, then Ho rejected and $\mathrm{Ha}$ received, meaning there is a significant influence between poverty rate and economic growth on Human Development Index in Indonesia. To find out the t-test of the Effect of Poverty Rate and the growth of the economic on the Human Development Index partially as seen above, the Effect of poverty on the Human Development Index in Indonesia with the t-value of 4,008 means that $\mathrm{t}->\mathrm{t}-$ table or $4,008>2.570$, so it can be said that the poverty rate has a significant influence on the Human Development Index in Indonesia, and The Effect of Economic Growth on Human Development Index in Indonesia of 3.363 means that $\mathrm{t}$-count $>\mathrm{t}-$ table or 3,363> 2,570, that Economic Growth has a significant influence on the Human Development Index in Indonesia.

\section{CLOSING}

1. Simultaneously the level of poverty and economic growth has a significant influence on the Human Development Index in Indonesia, this is evidenced by the acquisition of F-count> F-table or $8.292>5.41$,

2. The magnitude of the effect of poverty rate and economic growth on Human Development Index in Indonesia is evidenced by the R-square of 0.861 or $86.1 \%$ and the rest is influenced by other factors,

3. Partially the poverty rate has a significant influence on Human Development Index in Indonesia, it is proved by t-count> t-table or 4,008> 2,570 with the influence of Poverty Level to Human Development Index in Indonesia is 2,007\%, and

4. Partially Economic Growth has a significant influence on the Human Development Index in Indonesia, this is evidenced by t-count> t-table or $3.363>2.570$ with the size of the effect of Economic Growth on Human Development Index in Indonesia is $2.313 \%$

\section{BIBLIOGRAPHY}

Badan Pusat Statistik. 2017, "Indeks Pembangunan Manusia 2007-2008". Jakarta Indonesia.

Ginting dkk. 2008. "Pembangunan Manusia di Imdonesia dan FaktorFaktor yang Mempengaruhinya". Jurnal Perencanaan dan Pengembangan Wilayah. Vol.4, No.1, Agustus 2008. Hal 17-24.

Sukirno, Sadono. 2005. Makro Ekonomi, Teori Pengantar. Penerbit PT. Raja Grafindo Persada, Jakarta.

Todaro, M. 2006. Pengembangan Ekonomi Dunia Ketiga. Edisi Kedelapan. Jakarta: Penerbit Erlangga

www.bps.go.id www.undp.org 